\title{
Kvaliteta cvjetnog meda za potrebe Oružanih snaga Republike Hrvatske
}

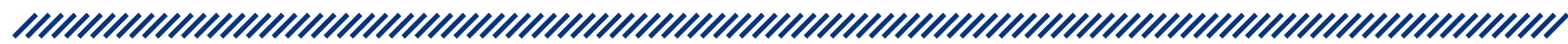

1 Nino Pinter

2 Željka Cvrtila

2 Lidija Kozačinski

2 Bela Njari

1 Služba za prijem i kontrolu kvalitete Uprave za materijalne resurse, Ministarstvo obrane RH, Zagreb

2 Zavod za higijenu, tehnologiju i sigurnost hrane, Veterinarski fakultet Sveučilišta u Zagrebu, Zagreb

\section{Sažetak}

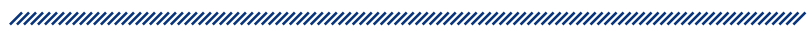

U okviru nadzora kvalitete cvjetnoga vrcanog meda za potrebe Oružanih snaga Republike Hrvatske koji se obavljao na mjestu proizvodnje pretražen je ukupno 41 uzorak meda. Fizikalno-kemijskim ispitivanjem 12 uzoraka dobiveni su sljedeći rezultati: količina vode iznosila je prosječno $16,52 \pm 0,85 \%(n=8)$, količina hidroksimetilfurfurala $11,41 \pm 8,26 \mathrm{mg} / \mathrm{kg}(n=12)$, ukupna kiselost iznosila je $16,78 \pm 2,30 \mathrm{mmol} / \mathrm{kg}(n=8)$, aktivnost dijastaze bila je $18,46 \pm 4,84 \mathrm{DN}(n=8)$. Udio saharoze prosječno je iznosio $2,47 \pm 2,05 \%(n=12)$, a direktno reducirajućih šećera $70,79 \pm 2,05 \%$ ( $n=7)$. Rezultati fizikalno-kemijskog ispitivanja nisu bili statistički značajni i pratili su normalnu distribuciju. Utvrđena je korelacija između udjela sadržaja vode i saharoze $(r=0,99 ; p=0,014)$ te udjela reducirajućih šećera i željeza $(r=-0,98 ; p=0,024)$. Postojala je korelacija između sadržaja vode i kadmija ( $r=0,93 ; p=0,072)$, aktivnosti dijastaze i željeza $(r=-0,94 ; p=0,056)$ te aktivnosti dijastaze i bakra $(r=-0,92 ; p=0,079)$ i količine reducirajućih šećera i bakra $(r=-0,94 ; p=0,065)$. Bakteriološkom pretragom nije bilo utvrđeno povećanje broja mikroorganizama u cvjetnom medu. Od 10 pretraženih uzoraka količina pesticida bila je u skladu s maksimalnim razinama ostataka pesticida u hrani. Analizom na teške metale srednja vrijednost količine olova iznosila je $0,04 \pm 0,016 \mathrm{mg} / \mathrm{kg}(\mathrm{n}=9), \mathrm{kadmija} 0,0058 \pm 0,0042 \mathrm{mg} /$ $\mathrm{kg}(\mathrm{n}=9)$, bakra 0,126 $\pm 0,179 \mathrm{mg} / \mathrm{kg}(\mathrm{n}=8)$, cinka $2,75 \pm 2,61 \mathrm{mg} / \mathrm{kg}(\mathrm{n}=8)$ i željeza 3,11 $\pm 3,27 \mathrm{mg} / \mathrm{kg}(\mathrm{n}=8)$. Lillieforsovim testom utvrđena je statistička značajnost olova $(p<0,01)$ te kadmija i bakra $(p<0,05)$. Utvrđena je korelacija između količine željeza i bakra ( $r=0,97$; $p=0,030)$. Postojala je korelacija između količine cinka i olova ( $r=0,95 ; p=0,055)$. Rezultati ispitivanja cvjetnoga vrcanog meda upućuju na zdravstveno ispravan med dobre kvalitete, u skladu s propisima Republike Hrvatske.

Ključne riječi: kvaliteta, med, Oružane snage Republike Hrvatske (OSRH)

Datum primitka: 14.04.2016.

Datum prihvaćanja: 15.05.2017.

DOI: $10.24141 / 3 / 1 / 13$

Adresa za dopisivanje:

Željka Cvrtila

Zavod za higijenu, tehnologiju i sigurnost hrane, Veterinarski fakultet Sveučilišta u Zagrebu

Heinzelova 55, 10000 Zagreb

E-pošta: zcvrtila@vef.hr

Tel.: +38512390192 


\section{Uvod}

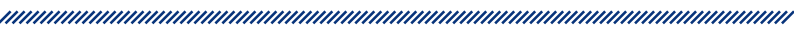

Med koji se nabavlja za potrebe Oružanih snaga Republike Hrvatske (OSRH) prema podrijetlu mora biti „cvjetni” ili „nektarni”, a može biti i uniflorni med. Prema načinu proizvodnje i/ili prezentiranja zahtijeva se vrcani med. Mora biti tekuće konzistencije, a poželjno je da nije kristaliziran. Med mora odgovarati svim uvjetima za „cvjetni” odnosno „nektarni” med koji su propisani Pravilnikom o medu, ${ }^{1}$ a ako je uniflorni, i odredbama Pravilnika o kakvoći uniflornog meda. ${ }^{2}$ Osim navedenog, med mora odgovarati i ostalim vrijedećim propisima Republike Hrvatske. S obzirom na namjenu, proizvod se može pakirati u posude zatvorene folijom, tube, vrećice ili neku drugu pogodnu ambalažu.

Pravilnikom o medu preuzete su Direktive Vijeća 2001/110/EZ iz 2001. godine koje se odnose na novi kriterij sastava meda te Direktive Vijeća 2000/13/EZ iz 2000. godine o usklađivanju propisa država članica koji se odnose na označavanje, prezentaciju i reklamiranje prehrambenih proizvoda. Kriterij je sastava za cvjetni med da zbroj količine fruktoze i glukoze mora biti najmanje $60 \mathrm{~g} / 100 \mathrm{~g}$, saharoze najviše $5 \mathrm{~g} / 100 \mathrm{~g}$, vode najviše $20 \%$, netopljivih tvari u vodi najviše $0,1 \mathrm{~g} / 100 \mathrm{~g}$, električna vodljivost najviše $0,8 \mathrm{mS} / \mathrm{cm}$, slobodnih kiselina najviše $50 \mathrm{mEq}$ kiseline na $1000 \mathrm{~g}$, aktivnost dijastaze (po Schedeu) najviše 8 i hidroksimetilfurfurala (HMF) najviše $40 \mathrm{mg} / \mathrm{kg}$.

Pri utvrđivanju pitanja izvornosti treba uzeti u obzir način dobivanja, zemljopisno podrijetlo i deklariranje meda. Postoji nekoliko preglednih dokumenata o utvrđivanju pitanja izvornosti meda.. ${ }^{3-7} \mathrm{U}$ državama Europske unije propisana je upotreba filtara za med veličine ne manje od 0,2 mm kako bi se spriječilo uklanjanje peluda. Prema međunarodnim i nacionalnim propisima takav med mora biti označen kao „filtrirani”. Međutim, primijećeno je da se najviše u Sjevernoj Americi pri pakiranju upotrebljavaju manji filtri da bi se izdvojili nepoželjni kontaminanti. ${ }^{7}$

Sadržaj vode u medu može se kretati između $13 \%$ i $23 \%$, ovisno o vrsti meda, klimatskim uvjetima i drugim čimbenicima. U zemljama s umjerenom klimom sadržaj vode u medu normalno se kreće ispod $18 \%$, ali može zbog klimatskih uvjeta i berbe sadržavati više od $20 \%$ vode. Med s manje od $17,1 \%$ vode smatra se sigurnim. Dodavanje vode pri krivotvorenju meda nije praktično s obzirom na fermentacijski rizik, osim ako sadržaj vode nije vrlo nizak. Suvišak vode se može otkloniti centrifugiranjem ili u vakuumskim isparivačima. ${ }^{7} \mathrm{U}$ literaturi su opisana mnogobrojna istraživanja udjela vode u različitim vrstama meda. ${ }^{8-12}$

Hidroksimetilfurfural (HMF), koji se određivao kao indikator za patvorenje meda, danas se upotrebljava pri procjeni kvalitete meda kao pokazatelj zagrijavanja i svježine meda. HMF je ciklički aldehid koji nastaje kiselom dehidracijom fruktoze i glukoze, ali može nastati i u Maillardovim reakcijama. ${ }^{13}$ Njegova količina utječe na kemijska svojstva meda. ${ }^{14,15}$ Osim temperature, količina HMF-a u medu raste tijekom vremena skladištenja, a ovisi o vrsti meda, pH-vrijednosti, udjelu kiselina i vlage. Svježi med obično sadrži do $10 \mathrm{mg} / \mathrm{kg}$ HMF-a. Nezagrijavani med trebao bi imati količinu HMF-a manju od $15 \mathrm{mg} / \mathrm{kg}$ te bi aktivnost invertaze trebala biti viša od 10 Hadornovih jedinica. ${ }^{16}$ Zagrijavanje monoflornog meda dovodi do povećanja količine HMF-a u medu. ${ }^{17}$ EU Direktiva 110/2001 i Pravilnik o medu definiraju da količina HMF-a u medu ne smije biti veća od $40 \mathrm{mg} / \mathrm{kg}$, osim meda iz područja s tropskom klimom - do 80 mg/ kg. ${ }^{1}$ Codex Alimentarius definira da sadržaj HMF-a nakon obrade i/ili miješanja ne smije biti veći od $80 \mathrm{mg} / \mathrm{kg} .{ }^{18}$ EU je predložila da bi „djevičanski med” trebao imati najviše sadržaj HMF-a od $25 \mathrm{mg} / \mathrm{kg} .{ }^{19}$

Najčešći je način krivotvorenja meda dodavanje zaslađivača ili otopine šećera za hranjenje pčela. Određivanje šećera dodanih u medu primjenjuje se metoda AOAC 977.20. Metodom masene spektrometrije utvrđuje se krivotvorenje meda šećerom od šećerne trske i kukuruznim sirupom, a temelji se na utvrđivanju omjera $13 \mathrm{C} / 12 \mathrm{C} .{ }^{20,21}$ Kukuruzni sirupi s visokom količinom fruktoze (HFC) često sadrže tragove visokih oligosaharida, koji normalno nisu prisutni u medu.

Prolin je bio predložen kao kriterij kvalitete s obzirom na krivotvorenje meda šećerom. Prirodni med ne bi trebao imati više od $180 \mathrm{mg} / \mathrm{kg}$ prolina, a niža količina prolina upućivala bi na sumnju da je med krivotvoren šećerom. ${ }^{22} \mathrm{U}$ ispitivanju monoflornog meda specifični su markeri aromatski spojevi i flavonoidi. Fenoli se primjenjuju za dokazivanje botaničkog porijekla. ${ }^{23}$

U svrhu utvrđivanja zdravstvene ispravnosti meda, određuju se toksični metali i metaloidi, pesticidi (organoklorirani, organofosforni, herbicidi, piretroidi), mikotoksini (aflatoksini B1, B2, G1, G2, M1, zearalenon - ZON, deoksinivalenol - DON i fumozini), antibiotici, sulfonamidi i aditivi (boje, konzervansi, antioksidansi, polifosfati, sladila, nitriti i nitrati), u skladu sa zakonskom regulativom. 
Cilj ovog rada bio je utvrditi kvalitetu cvjetnog vrcanog meda namijenjenog za potrebe Oružanih snaga Republike Hrvatske (OSRH).

\section{Materijal i metode}

Kod dobavljača je izvršen 21 nadzor u svrhu ocjene kvalitete cvjetnog meda. Dobavljači su posjedovali neke od međunarodnih certifikata kvalitete (HACCP, ISO 9001, IFS i/ili ISO 22000), a njihovi proizvodi nosili su oznaku „Hrvatska kvaliteta”. Cvjetni med nabavljan je direktno od pčelara na području Republike Hrvatske. Med je prerađen u odobrenim objektima, a laboratorijska ispitivanja kvalitete meda provedena su u laboratoriju dobavljača i u ovlaštenim institucijama. Uzorkovanje je bilo metodom slučajnog uzorkovanja. Laboratoriji su bili akreditirani prema normi HRN EN/IEC 17025:2007.

Prije analize uzorci su čuvani u originalnom pakiranju na sobnoj temperaturi, zaštićeni od svjetlosti, te su bili pripremljeni prema metodi AOAC 920.180, HRN EN 13804:2003 i HRN EN 12393-2:2008..$^{24-26}$

Kemijski parametri analizirani su u skladu s propisima Republike Hrvatske. ${ }^{1}$ Postotak vode određen je refraktometrijskim mjerenjem indeksa loma na $20^{\circ} \mathrm{C}$ prema metodi AOAC 969.38. Ukupna kiselost ( $\mathrm{mmol} / \mathrm{kg}$ ) određena je titracijskom metodom. Spektrofotometrijskom metodom (SLMB 6.1(23A):1995) i metodom po Schedeu - AOAC 958.09 određena je aktivnost dijastaze, a metodom HPLC količina udjela reduciranih šećera i saharoze. Količina hidroksimetilfurfurala (HMF mg/kg) određivana je spektrofotometrom Varian mod. Cary 1E UV-visible na $550 \mathrm{~nm}$ prema metodi AOAC $980.23 \mathrm{i}$ metodom HPLC s pomoću uređaja HPLC Varian $9012 \mathrm{Q}$ s detektorom Varian Star 330. Peludna analiza provedena je prema metodi DIN 10760:2002-05 Određivanje relativnog sadržaja peluda (Determination of relative pollen content).

Bakteriološkom pretragom određen je broj sulfitoreducirajućih klostridija (norma HRN ISO 15213:2004) i ICMSF 1968, potom ukupni broj aerobnih mezofilnih bakterija (norma HRN ISO 4833:2008), enterobakterije (norma HRN ISO 5552:1999) te kvasci i plijesni (norma HRN ISO 7954:2002).

Sadržaj teških metala utvrđen je razaranjem uzorka suhim spaljivanjem u mufolnoj peći i mjerenjem analita atomskom apsorpcijskom spektrofotometrijom (AAS). Sadržaj cinka, bakra i željeza određivan je plamenom tehnikom atomskom apsorpcijskom spektrofotometrom AAnalyst 400 - Perkin Elmer (PAAS), (Flame Technique Atomic Absorption Spectrometry, FAAS), prema normi HRN EN 14082:2005. Sadržaj kadmija i olova određen je grafitnom tehnikom atomskim apsorpcijskim spektrofotometrom AAnalyst 600 - Perkin Elmer (ET AAS), (Graphyte Furance Technique Atomic Absorption Spectrometry, GFAAS) prema normi HRN EN 14083:2005. ${ }^{25}$

Od ukupno 10 uzoraka analizom na pesticide utvrđena je količina alfa- $\mathrm{HCH}$, beta- $\mathrm{HCH}$, lindana, p,p-DDE, p,pDDD i p,p-DDT. Ostatci organoklornih pesticida (alfa$\mathrm{HCH}$, beta- $\mathrm{HCH}$, lindan, hepatoklor, p,p-DDE, p,p-DDD i p,p-DDT) određeni su plinskom kromatografijom prema normi HRN 12393:2008 na plinskom kromatografu Agilent GC $6850 \mathrm{~s}$ detektorom zahvata elektrona ( $\left.{ }^{63} \mathrm{Ni}\right)$ $(\mu \mathrm{ECD})$, injektorom splitless i kapilarnom kolonom J\&W Scientific DB 35 ms ili plinskim kromatografom Varian $3400 \mathrm{CX}$ s detektorom zahvata elektrona $\left({ }^{63} \mathrm{Ni}\right)$ (ECD), injektorom split/splitless i kapilarnom kolonom SPB $^{\text {TM }}-608 .{ }^{26}$

Podatci su obrađeni statističkim programom StatSoft, Inc. STATISTICA 8. Za svaku skupinu uzoraka izračunana je aritmetička sredina koncentracije analita, varijanca $\left(\mathrm{s}^{2}\right)$, standardna devijacija (SD) i koeficijent varijacije (KV\%). Kolmogorov-Smirnovljevim i Lillieforsovim testom utvrdila se statistička značajnost te normalna distribucija rezultata ispitivanja. Zatim je izvršena korelacijska analiza te sastavljen zaključak o vrijednosti koeficijenta korelacije (r) uz razinu vjerojatnosti $p<0,05$.

\section{Rezultati i rasprava}

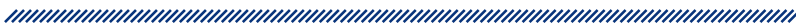

\subsection{Kemijska analiza}

Rezultati kemijske analize 12 uzoraka cvjetnog meda prikazani su u tablici 1 . U osam pretraženih uzoraka količina vode kretala se od 15,04 do $17,88 \%$, a srednja vrijednost bila je $16,52 \pm 0,85 \%$. Rezultati su bili normalno distribuirani. Prema Pravilniku o medu i Europskoj Direktivi Vijeća 2001/110/EZ za cvjetni med količina vode 
može biti najviše $20 \%,{ }^{1}$ a pretraženi uzorci meda sadržavali su količinu vode u skladu s vrijedećim propisima. U literaturnim podatcima ${ }^{27}$ navodi se da je od pet pretraženih uzoraka srednja vrijednost sadržaja vode iznosila $16,8 \pm 1,30 \%$ i kretala se od 15,5 do $18,6 \%, 2004$. od sedam uzoraka bila je 17,5 \pm 0,91 (16,4 - 18,6\%) i 2005. od 14 uzoraka iznosila je 17,0 $\pm 1,99 \%(14,6-20,6 \%)$. Naši su rezultati u skladu s dostupnim podatcima u istraživanjima ${ }^{28}$ na 40 uzoraka meda u kojima je količina sadržaja vode iznosila prosječno $17,3 \%$ i kretala se od 14,6 do $20,6 \%$.

Srednja vrijednost hidroksimetilfurfurala (HMF) od 12 uzoraka bila je $11,41 \pm 8,26 \mathrm{mg} / \mathrm{kg}$. Rezultati su bili normalno distribuirani. Količina HMF-a bila je u skladu s vrijedećim propisom koji navodi da može biti najviše $40 \mathrm{mg} / \mathrm{kg}$ HMF-a. ${ }^{1}$ Prema istraživanjima, ${ }^{27}$ srednja vrijednost količine HMF-a za cvjetni med ranijih godina bila je 3,5 $\pm 1,47 \mathrm{mg} / \mathrm{kg}$ i kretala se od 1,3 do 4,9 mg/ $\mathrm{kg}$, odnosno $10,2 \pm 9,29 \mathrm{mg} / \mathrm{kg}(1,9-27,4 \mathrm{mg} / \mathrm{kg})$ te $45,5 \pm 29,03 \mathrm{mg} / \mathrm{kg}(6,7-93,7 \mathrm{mg} / \mathrm{kg})$. Srednja vrijednost količine HMF-a od 29 uzoraka bila je $18,8 \mathrm{mg} / \mathrm{kg}$ (1,2 - 93,7 mg/kg). Naši su rezultati količine HMF-a niži, a raspon uži od rezultata navedenih rezultata.

Prosječna ukupna kiselost od osam uzoraka meda iznosila je 16,78 $\pm 2,30 \mathrm{mmol} / \mathrm{kg}$. Rezultati su bili normalno distribuirani. Količina slobodnih kiselina bila je u skladu s propisom koji navodi da može biti najviše $50 \mathrm{mEq}$ kiseline na 1000 g. ${ }^{1}$ Poznati podatci ${ }^{27}$ ukazuju da je od pet pretraženih uzoraka ukupna kiselost iznosila $18,0 \pm 4,8 \mathrm{mmol} / \mathrm{kg}$ i kretala se od 14,1 do $26,1 \mathrm{mmol} /$ $\mathrm{kg}$, u 2004. bila je $14,7 \pm 4,20 \mathrm{mmol} / \mathrm{kg}(9,1-21,5 \mathrm{mmol} /$ $\mathrm{kg}$ ) i konačno u 2005. iznosila je 12,1 $\pm 4,72 \mathrm{mmol} / \mathrm{kg}$ (5,1 - 20,4 mmol/kg). Srednja vrijednost ukupne kiselosti meda iznosila $16,3 \mathrm{mmol} / \mathrm{kg}(5,1-38,8 \mathrm{mmol} / \mathrm{kg})$.

Srednja vrijednost aktivnosti dijastaze od osam uzoraka iznosila je 18,46 $\pm 4,84$. Rezultati su bili normalno distribuirani. Aktivnost dijastaze bila je u skladu s propisom koji navodi da aktivnost dijastaze po Schedeu može biti najmanje 8. Prema našim autorima, ${ }^{27}$ od pet uzoraka u 2003. godini srednja vrijednost aktivnosti dijastaze iznosila je 26,0 i kretala se od 23,4 do 29,6; 2004. iznosila je 20,6 (10 - 29,3), a 2005. godine 18,1 (9,6 - 30,2). Drugi autor ${ }^{28}$ navodi da je od 42 uzoraka srednja vrijednost aktivnosti dijastaze $23,8(8,7-48,3)$. Naši su rezultati nešto niži.

Količina saharoze od 12 uzoraka kretala se od 0 do $4,64 \%$, a srednja vrijednost iznosila je 2,47 $\pm 2,05 \%$. Rezultati su bili normalno distribuirani. Količina saharoze bila je u skladu s propisom koji navodi da može biti najviše $5 \mathrm{~g} / 100 \mathrm{~g} .{ }^{1}$ Prema spomenutim autorima, ${ }^{27}$ od pet uzoraka u 2003. godini količina saharoze kretala se od 2,0 do 5,2 \%, a srednja vrijednost bila je 3,8 $\pm 1,36 \%$, u 2004. iznosila je $3,5 \pm 1,05 \%(1,8-4,8 \%)$ i u 2005 . godini $1,5 \pm 1,67 \%$ ( $0-4,4 \%)$. Drugi spomenuti autor ${ }^{28}$ navodi

\begin{tabular}{|c|c|c|c|c|c|c|c|}
\hline \multicolumn{7}{|c|}{ Tablica 1. Rezultati kemijske analize cvjetnog meda } \\
\hline & $\begin{array}{c}\text { Aritmetička } \\
\text { sredina }\end{array}$ & $\begin{array}{c}\text { Najmanja } \\
\text { vrijednost }\end{array}$ & $\begin{array}{c}\text { Najveća } \\
\text { vrijednost }\end{array}$ & $\begin{array}{c}\text { Varijacijska } \\
\text { sirina }\end{array}$ & Varijanca & $\begin{array}{c}\text { Standardna } \\
\text { devijacija }\end{array}$ & $\begin{array}{c}\text { Koeficijent } \\
\text { varijabilnosti } \\
(\%)\end{array}$ \\
\hline $\begin{array}{c}\text { Voda \% } \\
(n=8)\end{array}$ & 16,52 & 15,04 & 17,88 & 2,84 & 0,73 & 0,85 & 5,170 \\
\hline $\begin{array}{c}\text { HMF mg/kg } \\
\text { (n=12) }\end{array}$ & 11,407 & 2,78 & 25,42 & 22,64 & 68,30 & 8,26 & 72,45 \\
\hline $\begin{array}{c}\text { Ukupna } \\
\text { kiselost } \\
\text { mmol/kg } \\
(n=8)\end{array}$ & 16,78 & 12,70 & 19,87 & 7,17 & 5,31 & 2,30 & 13,73 \\
\hline $\begin{array}{c}\text { Aktivnost } \\
\text { dijastaze } \\
(n=8)\end{array}$ & 18,46 & 12,83 & 24,20 & 11,37 & 23,42 & 4,84 & 26,21 \\
\hline $\begin{array}{c}\text { Saharoza \% } \\
(n=12)\end{array}$ & 2,47 & 0 & 4,64 & 4,64 & 2,72 & 1,65 & 66,68 \\
\hline $\begin{array}{c}\text { Direktno } \\
\text { reducirajući } \\
\text { šć́ri \% } \\
(n=7)\end{array}$ & 70,79 & 68,82 & 74,99 & 6,17 & 4,22 & 2,05 & 2,90 \\
\hline
\end{tabular}


da je za 42 uzoraka srednja vrijednost količine saharoze iznosila 3,2 \% (0 - 18,1 \%). Od pretraženih sedam uzoraka srednja vrijednost direktno reducirajućih šećera bila je $70,79 \pm 2,05 \%$ i kretala se od 68,82 do $74,99 \%$. Rezultati su bili normalno distribuirani. Postotak direktno reduciranih šećera bio je u skladu s propisom o količini fruktoze i glukoze (zbroj) koja mora biti najmanje $60 \mathrm{~g} / 100 \mathrm{~g}$. Od pet pretraženih uzoraka u 2003. godini srednja vrijednost iznosila je $72,5 \pm 3,54 \%$ i kretala se od 66,6 do $75,8 \%$, u 2004 . iznosila je $71,6 \pm 2,61 \%$ $(67,4-75,1 \%)$ i u 2005 . godini bila je $68,7 \pm 2,18 \%$ odnosno u rasponu od 63,9 do $70,6 \% .{ }^{27}$ Nadalje, autor ${ }^{28}$ navodi da je za 42 uzoraka srednja vrijednost direktno reduciranih šećera iznosila 68,4 \% (57,9 - 87,2 \%). Naši su rezultati u skladu s citiranim podatcima.

Utvrđena je znatna korelacija između količine sadržaja vode i saharoze $(r=0,99 ; p=0,014$; slika 1$)$ te direktno reducirajućih šećera i željeza $\mathrm{mg} / \mathrm{kg}(r=-0,98 ; p=0,024$; slika 2). Postoji korelacija između količine sadržaja vode i kadmija $(r=0,93 ; p=0,072)$, aktivnosti dijastaze i željeza ( $r=-0,94 ; p=0,056)$, aktivnosti dijastaze i bakra $(r=-0,92 ; p=0,079)$ te direktno reducirajućih šećera $\mathrm{i}$ bakra $(r=-0,94 ; p=0,065)$. Podatci u literaturi29 navo- de da je utvrđena znatna korelacija između aktivnosti vrijednosti invertaze i dijastaze $(r=0,81 ; p<0,01)$ i između aktivnosti enzima i bakra (invertaza/Cu $r=0,52$; $p<0,05$; dijastaza/Cu $r=0,49 ; p<0,05$ ) te da nije bilo znatnih korelacija između aktivnosti enzima i sadržaja HMF-a.

\subsection{Bakteriološka analiza}

U svih 10 pretraženih uzoraka cvjetnog meda utvrđen je broj aerobnih mezofilnih bakterija < $10000 \mathrm{cfu} / \mathrm{g}$, Enterobacteriaceae $<10 \mathrm{cfu} / \mathrm{g}$, sulfitoreducirajućih klostridija < $10 \mathrm{cfu} / \mathrm{g}$, kvasaca < $100 \mathrm{cfu} / \mathrm{g}$ i plijesni < $100 \mathrm{cfu} / \mathrm{g}$ (tablica 2). Broj mikroorganizama u medu nije bio povećan, već u skladu s Vodičem za mikrobiološke kriterije za hranu ${ }^{30}$ i propisom o mikrobiološkim kriterijima za med. ${ }^{31-33}$

\subsection{Analiza na pesticide}

Količina alfa-HCH i beta- $\mathrm{HCH}$ u 10 pretraženih uzoraka iznosila je od $<0,0001 \mathrm{mg} / \mathrm{kg}$ do $<0,01 \mathrm{mg} / \mathrm{kg}$, lindana od $<0,0001 \mathrm{mg} / \mathrm{kg}$ do $<0,01 \mathrm{mg} / \mathrm{kg}$, dok je p,p-DDE, p,pDDD i p,p-DDT iznosio od $<0,0001 \mathrm{mg} / \mathrm{kg}$ do $0,01 \mathrm{mg} / \mathrm{kg}$

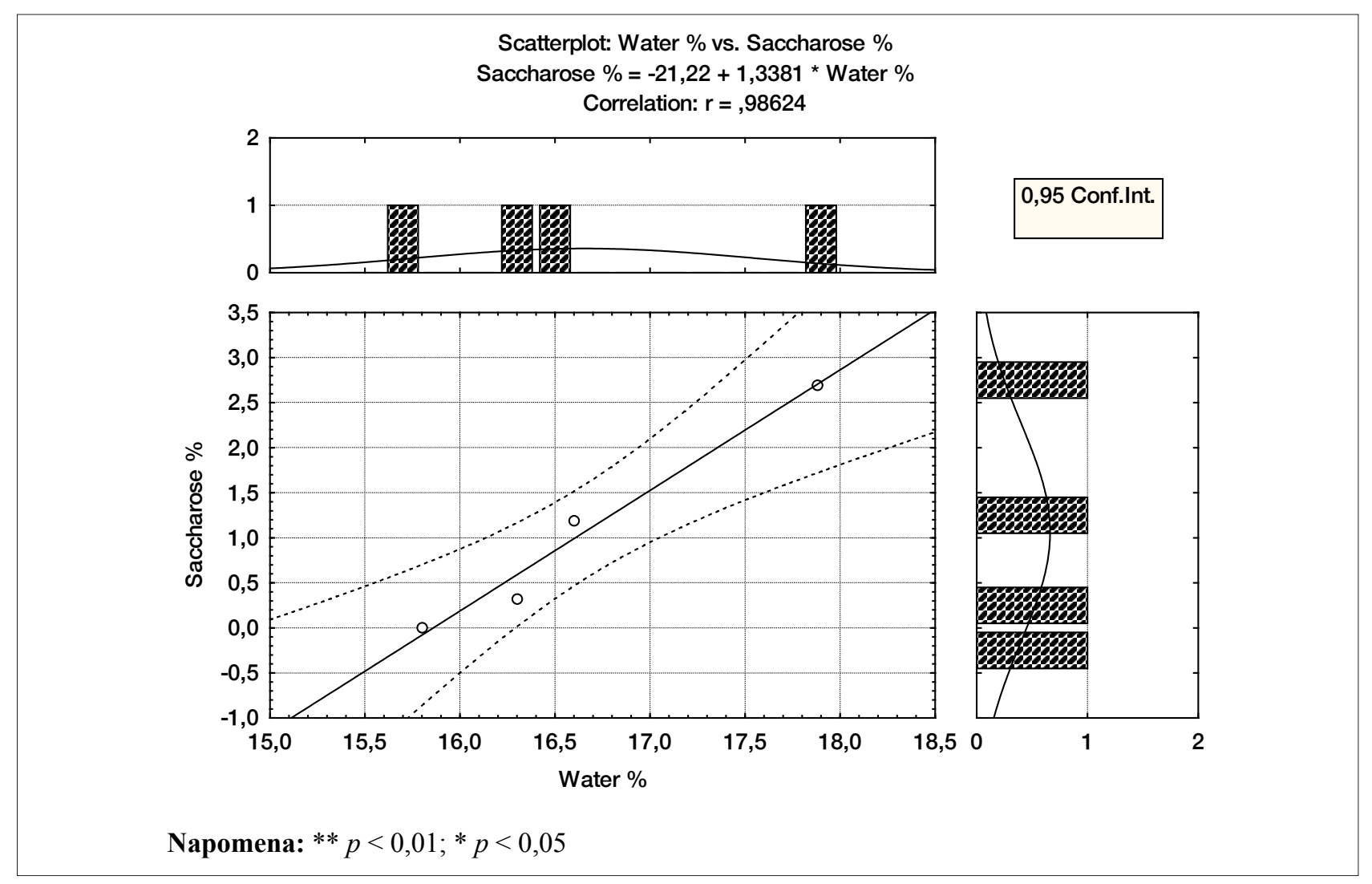

Slika 1. Korelacija između količine sadržaja vode i saharoze u cvjetnom medu $(p<0,05)$ 


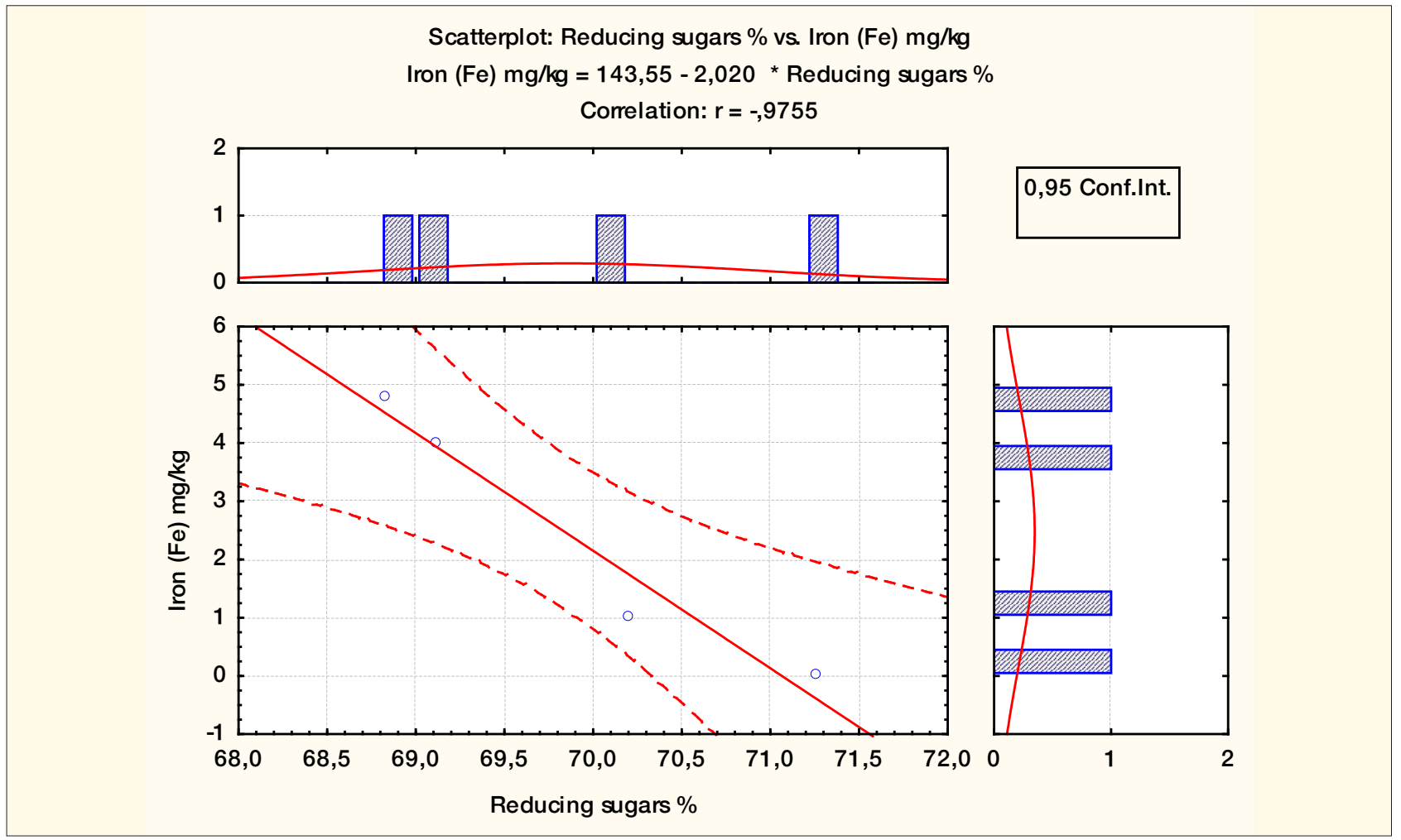

Slika 2. Korelacija između količine reducirajućih šećera i željeza u cvjetnom medu $(p<0,05)$

\begin{tabular}{|c|c|c|c|c|c|}
\hline $\begin{array}{l}\text { Uzorak } \\
(n=10)\end{array}$ & $\begin{array}{c}\text { Sulfitoreducirajuće } \\
\text { klostridije } \\
\text { cfu/g }\end{array}$ & $\begin{array}{c}\text { Enterobacteriaceae } \\
\mathrm{cfu} / \mathrm{g}\end{array}$ & $\begin{array}{c}\text { Aerobne } \\
\text { mezofilne } \\
\text { bakterije } \\
\text { cfu/g }\end{array}$ & $\begin{array}{l}\text { Kvasci } \\
\mathrm{cfu} / \mathrm{g}\end{array}$ & $\begin{array}{l}\text { Pljesni } \\
\mathrm{cfu} / \mathrm{g}\end{array}$ \\
\hline 1 & $<10$ & $<10$ & $<10000$ & $<100$ & $<100$ \\
\hline 2 & $<10$ & $<10$ & $<10000$ & $<100$ & $<100$ \\
\hline 3 & $<10$ & $<10$ & $<10000$ & $<100$ & $<100$ \\
\hline 4 & $<10$ & $<10$ & $<10000$ & $<100$ & $<100$ \\
\hline 5 & $<10$ & $<10$ & $<10000$ & $<100$ & $<100$ \\
\hline 6 & $<10$ & $<10$ & $<10000$ & $<100$ & $<100$ \\
\hline 7 & $<10$ & $<10$ & $<10000$ & $<100$ & $<100$ \\
\hline 8 & $<10$ & $<10$ & $<10000$ & $<100$ & $<100$ \\
\hline 9 & $<10$ & $<10$ & $<10000$ & $<100$ & $<100$ \\
\hline 10 & $<10$ & $<10$ & $<10000$ & $<100$ & $<100$ \\
\hline
\end{tabular}




\begin{tabular}{|c|c|c|c|c|c|c|}
\hline $\begin{array}{c}\text { Uzorak } \\
\text { (sample) } \\
(\mathrm{n}=10)\end{array}$ & $\begin{array}{l}\text { alfa-HCH } \\
\mathrm{mg} / \mathrm{kg}\end{array}$ & $\begin{array}{l}\text { beta-HCH } \\
\mathrm{mg} / \mathrm{kg}\end{array}$ & $\begin{array}{l}\text { Lindan mg/ } \\
\text { kg }\end{array}$ & $\begin{array}{c}\text { pp-DDE mg/ } \\
\text { kg }\end{array}$ & $\begin{array}{c}\mathrm{pp}-\mathrm{DDD} \mathrm{mg} / \\
\mathrm{kg}\end{array}$ & $\begin{array}{c}\text { pp-DDT mg/ } \\
\text { kg }\end{array}$ \\
\hline 1 & $<0,0001$ & $<0,0001$ & $<0,0001$ & $<0,0001$ & $<0,0001$ & $<0,0001$ \\
\hline 2 & $<0,002$ & $<0,002$ & $<0,002$ & $<0,002$ & $<0,002$ & $<0,002$ \\
\hline 3 & $<0,002$ & $<0,002$ & $<0,002$ & $<0,002$ & $<0,002$ & $<0,002$ \\
\hline 4 & $<0,001$ & $<0,001$ & $<0,001$ & $<0,001$ & $<0,001$ & $<0,001$ \\
\hline 5 & $<0,001$ & $<0,001$ & $<0,001$ & $<0,001$ & $<0,001$ & $<0,001$ \\
\hline 6 & $<0,002$ & $<0,002$ & $<0,002$ & $<0,002$ & $<0,002$ & $<0,002$ \\
\hline 7 & $<0,002$ & $<0,002$ & $<0,002$ & $<0,002$ & $<0,002$ & $<0,002$ \\
\hline 8 & $<0,001$ & $<0,001$ & $<0,001$ & $<0,001$ & $<0,001$ & $<0,001$ \\
\hline 9 & $<0,002$ & $<0,002$ & $<0,002$ & $<0,002$ & $<0,002$ & $<0,002$ \\
\hline 10 & $<0,01$ & $<0,01$ & $<0,01$ & $<0,01$ & $<0,01$ & $<0,01$ \\
\hline
\end{tabular}

(tablica 3). Utvrđena količina pesticida bila je u skladu s Pravilnikom o maksimalnim razinama ostataka pesticida u i na hrani za životinje biljnog i životinjskog porijekla. ${ }^{34-37}$

\subsection{Analiza na teške metale}

Analizom na teške metale (tablica 4) od devet uzoraka količina olova $(\mathrm{Pb})$ kretala se od $<0,01 \mathrm{mg} / \mathrm{kg}$ do $<0,05 \mathrm{mg} /$ $\mathrm{kg}$. Srednja vrijednost iznosila je 0,04 $\pm 0,016 \mathrm{mg} / \mathrm{kg}$. Kolmogorov-Smirnovljevim i Lillieforsovim testom utvrdila se statistička značajnost te normalna distribucija rezultata ispitivanja (slika 3).
Količina kadmija kretala se od 0,001 mg/kg do $<0,01 \mathrm{mg} /$ $\mathrm{kg}$. Srednja vrijednost od devet pretraženih uzoraka iznosila je 0,0058 $\pm 0,004 \mathrm{mg} / \mathrm{kg}$. Kolmogorov-Smirnovljevim testom dobivena je $p$-vrijednost $p>0,20(\mathrm{~d}=0,28)$, a Lillieforsovim testom $p<0,05$. Rezultati su bili statistički značajni i nisu pratili normalnu distribuciju (slika 4).

Od pretraženih osam uzoraka količina bakra kretala se od $<0,02 \mathrm{mg} / \mathrm{kg}$ do $0,5 \mathrm{mg} / \mathrm{kg}$. Srednja vrijednost iznosila je 0,126 $\pm 0,179 \mathrm{mg} / \mathrm{kg}$. Kolmogorov-Smirnovljevim dobivena je $p$-vrijednost $p>0,20(d=0,33)$, a Lillieforsovim testom $p<0,05$. Rezultati su bili statistički značajni i nisu pratili normalnu distribuciju (slika 5).

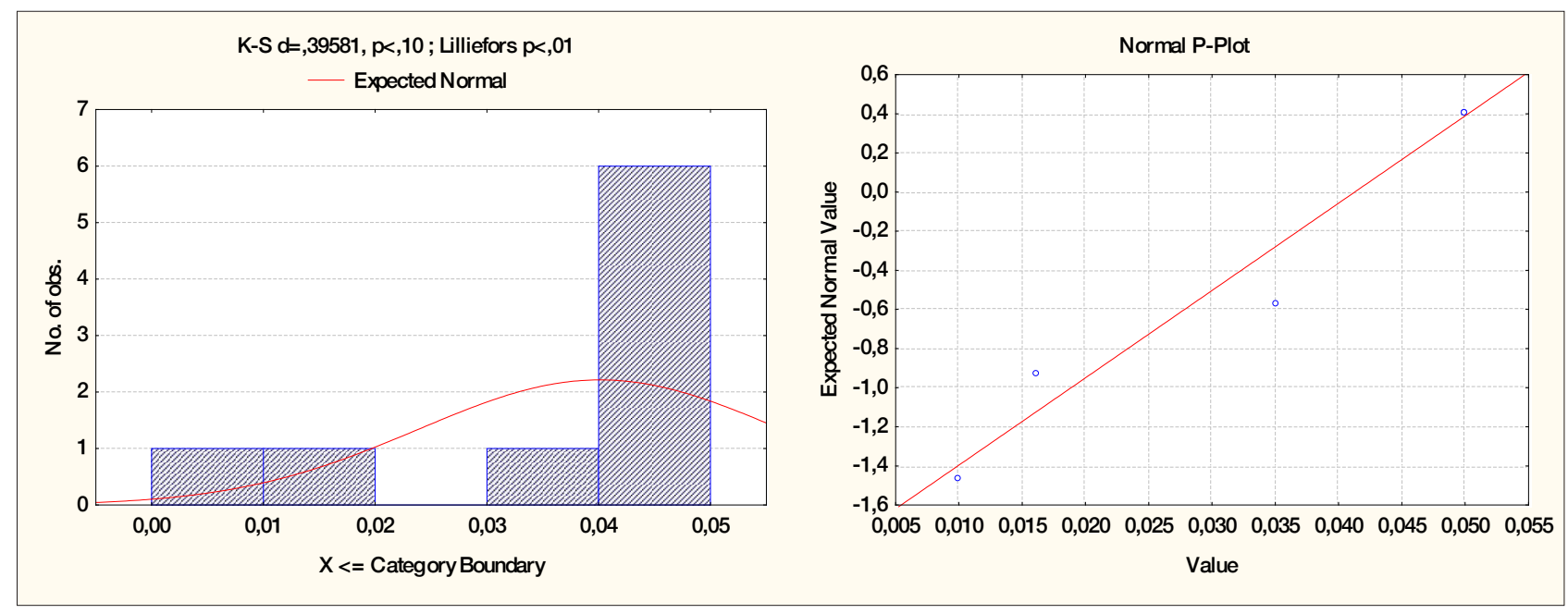




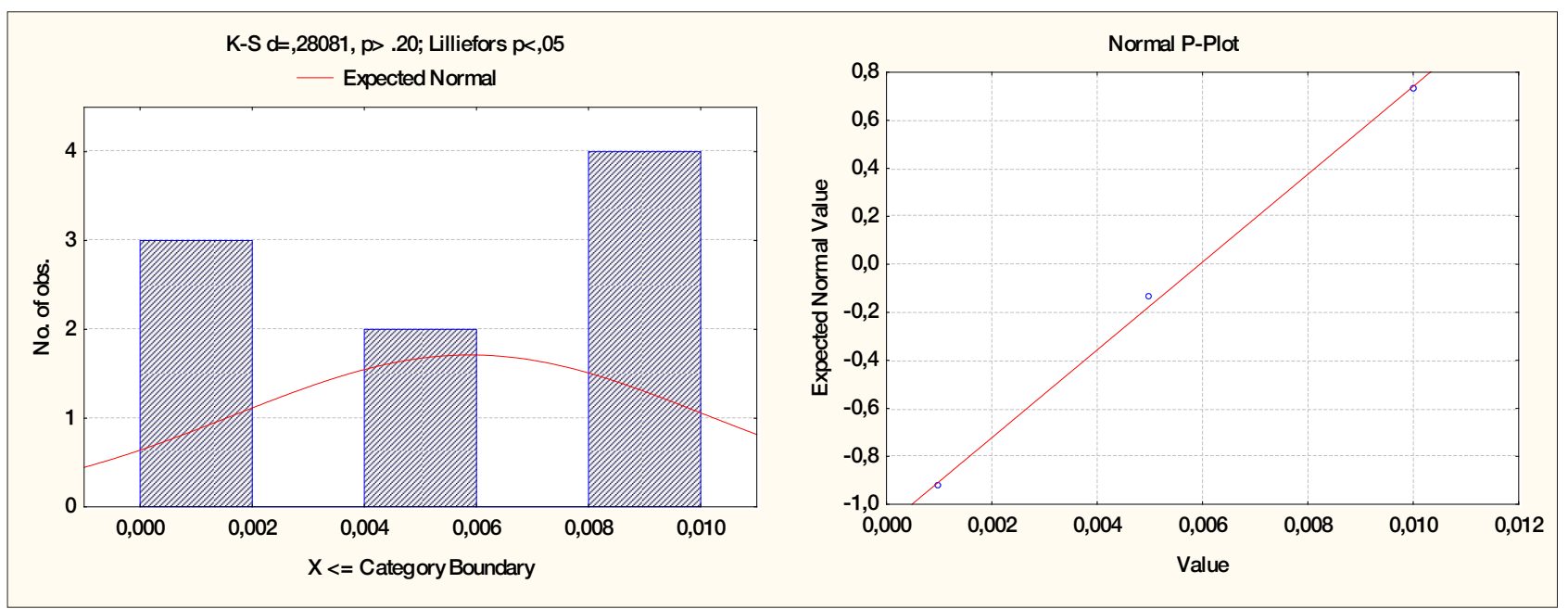

Slika 4. Količina kadmija mg/kg u cvjetnom medu $(p<0,05)$

Količina cinka u osam uzoraka kretala se od $<0,01 \mathrm{mg} / \mathrm{kg}$ do $7,62 \mathrm{mg} / \mathrm{kg}$. Srednja vrijednost bila je $2,74 \pm 2,61 \mathrm{mg} /$ kg. Rezultati su bili normalno distribuirani.

U svih pretraženih osam uzoraka količina željeza kretala se od $<0,01 \mathrm{mg} / \mathrm{kg}$ do $7,4 \mathrm{mg} / \mathrm{kg}$. Srednja vrijednost iznosila je 3,11 $\pm 3,27 \mathrm{mg} / \mathrm{kg}$. Rezultati su bili normalno distribuirani. Rezultati nisu bili statistički značajni i pratili su normalnu distribuciju.

U dostupnim istraživanjima ${ }^{38}$ navodi se da prosječna količina kadmija iznosi od 0,008 do 0,027 mg/kg, a srednja vrijednost bila je $0,015 \mathrm{mg} / \mathrm{kg}$. Količina cinka se kretala od 4,17 do $22,3 \mathrm{mg} / \mathrm{kg}$, a srednja vrijednost iznosila je $7,76 \mathrm{mg} / \mathrm{kg}$. Prosječna količina olova kretala se od 0,025 do $0,071 \mathrm{mg} / \mathrm{kg}$, a srednja vrijednost iznosila je $0,048 \mathrm{mg} / \mathrm{kg}$. Istraživanja provedena u Poljskoj pokazala su velike oscilacije količine teških metala u medu. ${ }^{39}$ Velike količine teških metala pronađene su u medu iz košnica u blizini urbanih cesta i čeličana. Talijanski znanstvenici navode da su otkrili velike količine cinka, kadmija i olova u medu te su pronašli linearni odnos između količine kadmija u medu i u cvijeću Trifolium pratense ${ }^{40}$. Također se navodi da se med može promatrati i kao ekološki marker onečišćenja okoliša.

Znatna korelacija elemenata u tragovima bila je utvrđena između količine željeza i bakra $(r=0,97 ; p=0,030$; slika 6). Postojala je korelacija između količine cinka i olova $(r=0,95 ; p=0,055)$.

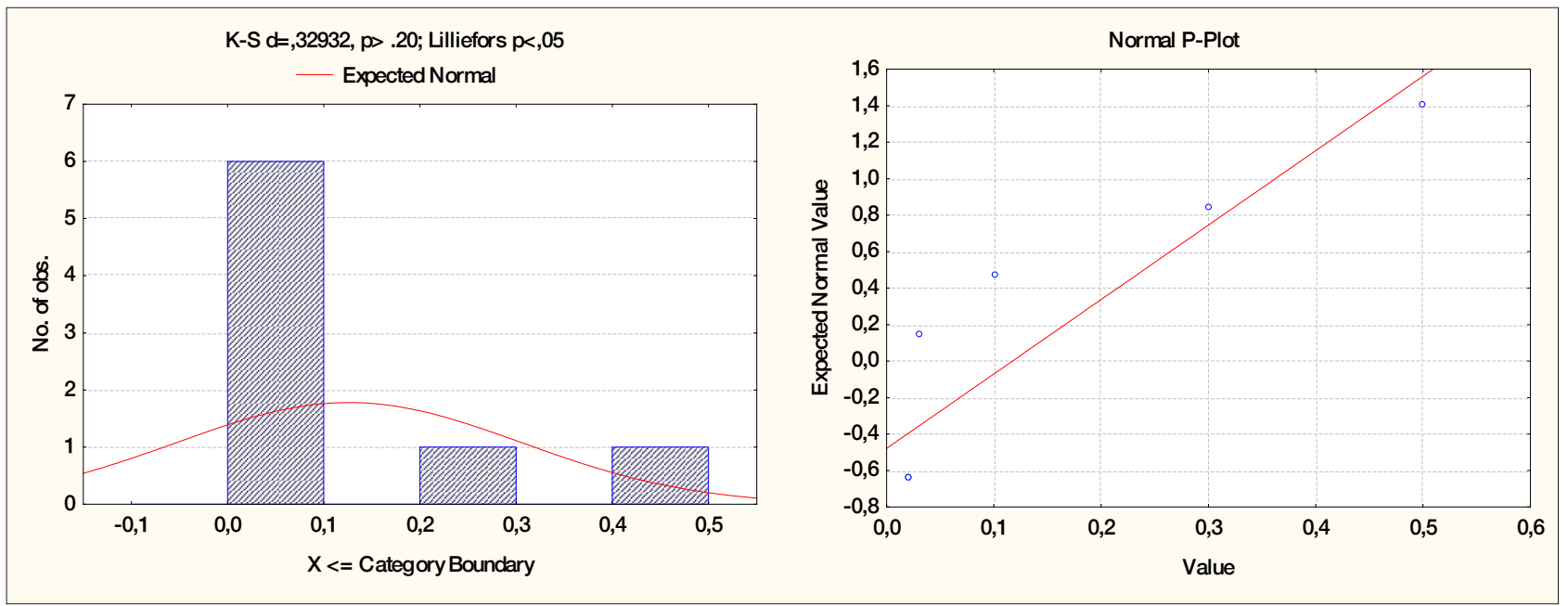

Slika 5. Količina bakra $(\mathrm{mg} / \mathrm{kg}) \mathrm{u}$ cvjetnom medu $(p<0,05)$ 


\begin{tabular}{|c|c|c|c|c|c|c|c|}
\hline & $\begin{array}{l}\text { Aritmetička } \\
\text { sredina }\end{array}$ & $\begin{array}{l}\text { Najmanja } \\
\text { vrijednost }\end{array}$ & $\begin{array}{c}\text { Najveća } \\
\text { vrijednost }\end{array}$ & $\begin{array}{c}\text { Varijacijska } \\
\text { širina }\end{array}$ & Varijanca & $\begin{array}{l}\text { Standardna } \\
\text { devijacija }\end{array}$ & $\begin{array}{c}\text { Koeficijent } \\
\text { varijabilnosti } \\
(\%)\end{array}$ \\
\hline 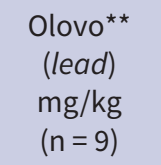 & 0,0401 & 0,01 & 0,05 & 0,04 & 0,00026 & 0,016 & 40,40 \\
\hline $\begin{array}{c}\text { Kadmij } \\
\text { (cadmium) } \\
\mathrm{mg} / \mathrm{kg} \\
(\mathrm{n}=9)\end{array}$ & 0,0058 & 0,001 & 0,01 & 0,009 & 0,00002 & 0,004 & 71,26 \\
\hline $\begin{array}{c}\text { Bakar* }^{*} \\
\text { (copper) } \\
\mathrm{mg} / \mathrm{kg} \\
(\mathrm{n}=8)\end{array}$ & 0,126 & 0,02 & 0,05 & 0,03 & 0,03214 & 0,179 & 142,00 \\
\hline $\begin{array}{c}\text { Cink } \\
\text { (zinc) } \\
\mathrm{mg} / \mathrm{kg} \\
(\mathrm{n}=8)\end{array}$ & 2,75 & 0,01 & 7,62 & 7,61 & 6,81 & 2,61 & 95,05 \\
\hline $\begin{array}{c}\text { Željezo } \\
\text { (iron) } \\
\text { mg/kg } \\
(n=8)\end{array}$ & 3,11 & 0,01 & 7,74 & 7,73 & 10,72 & 3,27 & 105,34 \\
\hline
\end{tabular}

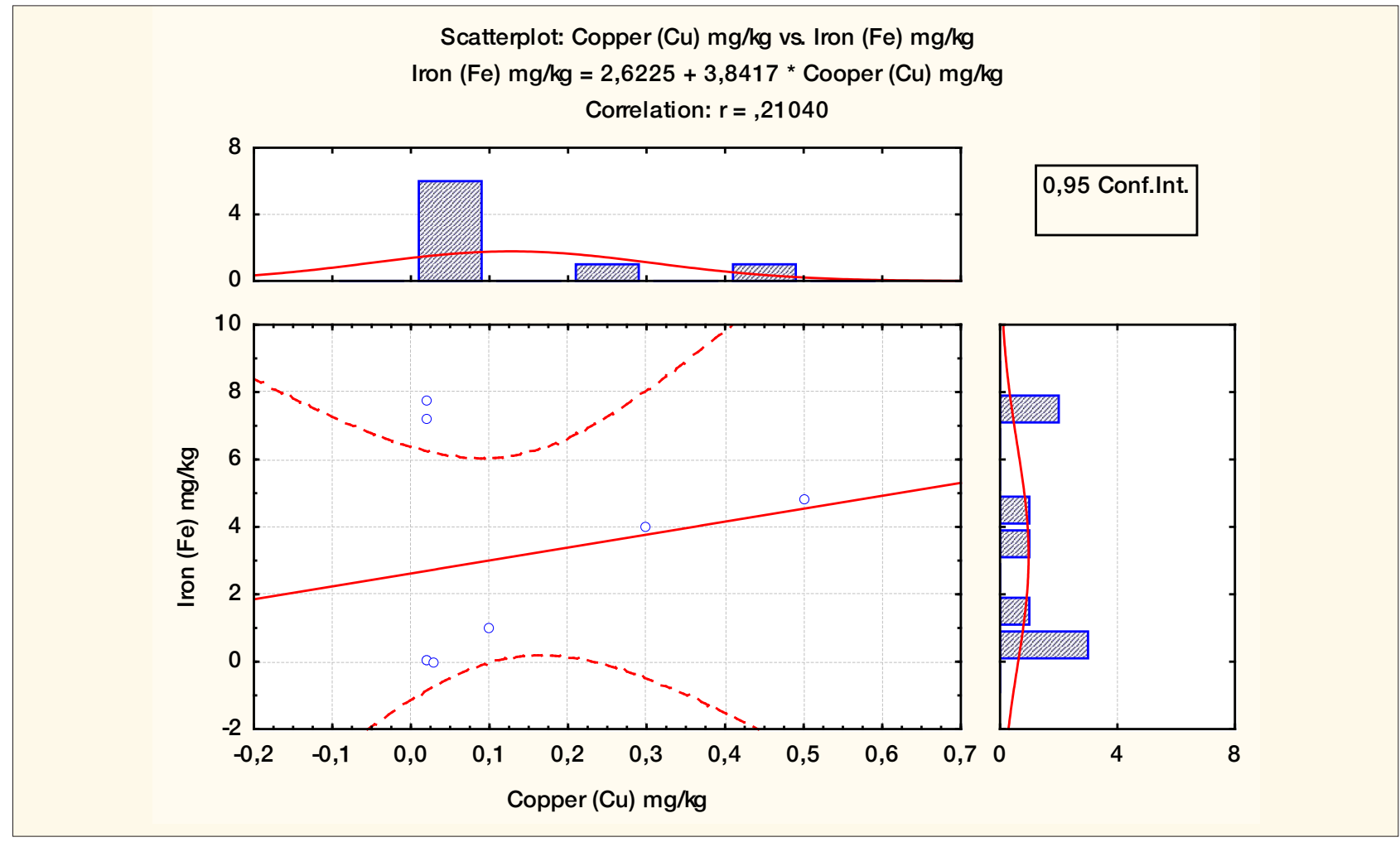




\section{Zaključak}

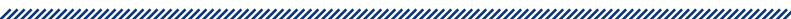

Na temelju rezultata ispitivanja cvjetnoga vrcanog meda za potrebe OSRH-a možemo zaključiti da su svi ispitani uzorci cvjetnog meda bili zdravstveno ispravni, dobre kvalitete i u skladu s vrijedećim propisima Republike Hrvatske. Utvrđena je znatna korelacija između količine sadržaja vode i saharoze $(r=0,99 ; p=0,014)$ te između količine reducirajućih šećera i željeza $(r=-0,98 ; p=0,024)$. Postojala je korelacija između količine aktivnosti dijastaze i željeza ( $r=-0,94 ; p=0,056)$. Lillieforsovim testom utvrđena je statistička značajnost olova $(p<0,01)$ te kadmija i bakra $(p<0,05)$. Utvrđena je značajna korelacija elemenata u tragovima $(p<0,05)$ između količine željeza i bakra $(r=0,97 ; p=0,030)$. Postojala je korelacija između količine cinka i olova $(r=0,94 ; p=0,055)$.

\section{Literatura}

1. Ministarstvo poljoprivrede. Pravilnik o medu. Narodne novine 53/2015.

2. Ministarstvo poljoprivrede, ribarstva i ruralnog razvoja. Pravilnik o kakvoći uniflornog meda. Narodne novine 122/2009.

3. Molan P. Authenticity of honey. U: Ashhurst PR, Dennis M (ur.): Food authentication. London: Blackie; 1996.

4. Singhal R, Kulkarni P, Rege D. Handbook of indices of food quality and authenticity. Cambridge: Woodhead publishing; 1997. 7. poglavlje: Honey: quality criteria; str. 358-385.

5. Anklam E. A review of the analytical methods to determine the geographical and botanical origin of honey. Food Chem. 1998; 63(4): 549-562.

6. Martin P, Sharman M, Scotter CN. Honey - product definition and manufacturing processes. U: Lees $M$ (ur.): Food authenticity - issues and methodologies. Nantes: Eurofins Scientific; 1998.

7. Bogdanov S, Martin P. Honey Authenticity: a Review. Bern: Swiss Bee Research Centre. 2002.

8. Singh N, Bath PK. Quality evaluation of different types of Indian honey. Food Chem. 1997; (58): 129-133.

9. Andrade PB, Amaral MT, Isabel P, Carvalho JC, Seabra RM, de Cunha AP. Physicochemical attributes and pollen spectrum of Portuguese heather honeys. Food Chem. 1999; (66): 503-510.
10. Joshi S, Pechhacker RH, William A, Von der Ohe W. Physico-chemical characteristics of Apis dorsata, A. Cerana and A. Mellifera honey from Chitwan district, central Nepal. Apidologie. 2000; (31): 367-375.

11. Terrab A, Diez MJ. Heredia FJ. Characterization of Moroccan unifloral honeys by their physicochemical characteristics. Food Chem. 2002; (79): 373-379.

12. De Rodriguez GO, Ferrer BS, Ferrer A, Rodriguez B. Characterization of honey produced in Venezuela. Food Chem. 2004; (84): 499-502.

13. Belitz HD, Grosch W. Food Chemistry. Berlin: SpringerVerlag; 1999.

14. Bogdanov S, Martin P, Lüllmann C. Harmonised method of the European Honey Commision. Apidologie. 1997 (posebno izdanje); 59.

15. Singh N, Bath PK. Relationship between heating and hydroxymethylfurfural formation in different honey types. Journal of Food Science and Technology. 1998; (35): 154-156.

16. Duisberg $\mathrm{H}$, Hadorn $\mathrm{H}$. Welche Anforderungen sind an Handelshonige zu stellen? Mitt Lebensm Hyg. 1966; (57): 386-407.

17. Fallico B, Zappala M, Arena E, Verzera A. Effects of heating process on chemical composition and HMF levels in Sicilian monofloral honeys. Food Chem. 2004; (85):3 05-313.

18. Codex Alimentarius. Draft revised standard for honey (at step 10 of the Codex procedure). Alinorm. 2001; (25): 19-26.

19. Council of the European Union. Application for registration of a certificate of specific character, Council Regulation No. 2082/92. Official Journal of the European Communities C 2002; (63): 23-24.

20. White JW, Doner LW. Mass spectrometric detection of high-fructose corn sirup in honey by use of $13 \mathrm{C} / 12 \mathrm{C}$ ratio: Collaborative study. J Assoc Off Anal Chem. 1978; (61): 746-750.

21. Brookes ST, Barrie A, Davies JE. A rapid 13C/12C test for determination of corn syrups in honey. J Assoc Off Anal Chem. 1991;(74):627-629.

22. Von der Ohe W, Dustmann JH, Von der Ohe K. Prolin als Kriterium der Reife des Honigs. Dtsch. Lebensm. Rundsch. 1991;(87):383-386.

23. Conte L, Piasenzotto S, Bogdanov K, Rouff J, Sanz J, Denemont J. Determination of honey volatiles in relation to their botanical origin. Simpozij „II Ruolo della ricerca in apicoltura“, Bologna, 2002; 247-252.

24. HRN EN 13804:2003 - Određivanje elemenata u tragovima - Izvedbeni kriteriji, opća razmatranja i priprava uzoraka (EN 13804:2002), (engl. Foodstuffs - Determination of trace elements - Performance criteria, general considerations and sample preparation (EN 13804:2002)). Hrvatski zavod za norme (HZN), prvo izdanje, 10-12/2003, 1-15.

25. HRN EN 14084:2005 - Namirnice - Određivanje elemenata u tragovima - Određivanje olova, kadmija, cinka, bakra i željeza atomskom apsorpcijskom spektrometrijom na- 
kon mikrovalne razgradnje (EN 14084:2003), (engl. Foodstuffs - Determination of trace elements - Determination of lead, cadmium, zinc, copper and iron by atomic absorption spectrometry (AAS) after microwave digestion (EN 14084:2003)). Hrvatski zavod za norme (HZN), prvo izdanje, 2/2005, 1-17.

26. HRN EN 12393-2:2008 - Hrana biljnog porijekla - Multirezidualne metode za određivanje ostataka pesticida plinskom kromatografijom - 2. dio: Metode ekstrakcije $i$ čišćenja (EN 12393-2:2008), (engl. Foods of plant origin Multiresidue methods for the gas chromatographic determination of pesticide residues - Part 2: Methods for extraction and cleanup (EN 12393-2:2008)). Hrvatski zavod za norme (HZN), drugo izdanje, 6/2008, 1-39.

27. Šarić $G$, Matković $D$, Hruškar M, Vahčić N. Characterization and classification of Croatian honey by physicochemical parameters. Food Technol Biotechnol. 2008; (46): 355-367.

28. Rogulja D. Kemijske, fizikalne i senzorske značajke meda [internet]. Pčelinjak - Udruga pčelara neposrednih proizvođača. 2009. Dostupno na: http://www.pcelinjak.hr/OLD/index. php/Prehrana-i-biotehnologija/kemijske-fizikalne-i-senzorske-znaajke-med.html (pristupljeno 1. svibnja 2017.).

29. Vorlová L, Čelechovská O. Activity of Enzymes and Trance Element Content in Bee Honey. Acta Vet. Brno. 2002; (71): 375-378.

30. Vodič za mikrobiološke kriterije za hranu. 2. izmijenjeno izdanje. Ministarstvo poljoprivrede, ribarstva i ruralnog razvoja: 2010; $1-77$.

31. Ministarstvo poljoprivrede, ribarstva i ruralnog razvoja. Pravilnik o mikrobiološkim kriterijima za hranu. Narodne novine 74/2008.

32. Ministarstvo poljoprivrede, ribarstva i ruralnog razvoja. Pravilnik o izmjenama i dopunama Pravilnika o mikrobiološkim kriterijima za hranu. Narodne novine 156/2008.
33. Ministarstvo poljoprivrede, ribarstva i ruralnog razvoja. Pravilnik o izmjenama i dopunama Pravilnika o mikrobiološkim kriterijima za hranu. Narodne novine 89/2010.

34. Ministarstvo poljoprivrede, ribarstva i ruralnog razvoja. Pravilnik o maksimalnim razinama ostataka pesticida u hrani i hrani za životinje. Narodne novine 119/2007.

35. Ministarstvo poljoprivrede, ribarstva i ruralnog razvoja. Pravilnik o maksimalnim razinama ostataka pesticida u i na hrani i hrani za životinje biljnog i životinjskog porijekla. Narodne novine 148/2008.

36. Ministarstvo poljoprivrede, ribarstva i ruralnog razvoja. Pravilnik o izmjenama i dopunama Pravilnika o maksimalnim razinama ostataka pesticida u i na hrani i hrani za životinje biljnog i životinjskog porijekla. Narodne novine 36/2010.

37. Ministarstvo poljoprivrede, ribarstva i ruralnog razvoja. Pravilnik o izmjenama i dopunama Pravilnika o maksimalnim razinama ostataka pesticida u i na hrani i hrani za životinje biljnog i životinjskog porijekla. Narodne novine 26/2011.

38. Przybylowski P, Wilczyńska A. Honey as an environmental marker. Food Chem. 2001; (74): 289-291.

39. Buliński R, Wyszogrodzka-Koma L, Marzec Z. Badanie zawartości niektórych pierwiastków śladowych w produktach spożywczych krajowego pochodzenia [Study of some trace elements content of home food products]. Brom Chem Toksykol. 1995; 28(2): 151.

40. Leita L, Muhlbachova G, Cresco S, Barbattini R, Mondini $C$. Investigation of the use of honey bees and honey bee product to assess heavy metals contamination. Environ Monit Assess. 1996; 43(1): 1-9. 


\section{THE QUALITY FLORAL HONEY FOR THE NEEDS OF THE CROATIAN ARMED FORCES}

\footnotetext{
1 Nino Pinter

2 Željka Cvrtila

2 Lidija Kozačinski

2 Bela Njari
}

1 Reception and Quality Control Service of Material Resources Directorate, Ministry of Defence of the Republic of Croatia, Zagreb

2 Department of Hygiene, Technology and Food Safety, Veterinary Faculty, University of Zagreb, Zagreb

\section{Abstract}

In the quality supervision for the needs of the Croatian Armed Forces (CAF) a total of 41 samples were taken for physical, chemical and bacteriological tests and analyzed for the presence of pesticides and heavy metals. Physical and chemical testing of 12 samples found that the amount of water averaged $16.52 \pm 0.85 \%$ ( $n=$ 8), hydroxymethylfurfural $11.41 \pm 8.26 \mathrm{mg} / \mathrm{kg}(\mathrm{n}=12)$, total acidity was $16.78 \pm 2.30 \mathrm{mmol} / \mathrm{kg}(\mathrm{n}=8)$, and diastase activity was $18.46 \pm 4.84 \mathrm{DN}(n=8)$. The share of sucrose averaged $2.47 \pm 2.05 \%(n=12)$, and of directly reducing sugars $70.79 \pm 2.05 \%(n=7)$. The results of physical and chemical tests were not statistically significant and followed the normal distribution. There was a correlation between the proportion of the water content and sucrose $(r=0.99, p=0.014)$, and the content of reducing sugar and iron $(r=-0.98, p=0.024)$. There was a correlation between water content and cadmium $(r=0.93, p=0.072)$, diastase activity and iron $(r=-0.94$, $p=0.056)$ and diastase activity and copper $(r=-0.92, p$ $=0.079$ ) and the amount of reducing sugars and copper $(r=-0.94, p=0.065)$. Bacterial tests did not find an increase of the number of microorganisms in flower honey. Of the 10 samples, the amount of pesticides was in line with the maximum residue levels of pesticides in food. The analysis of heavy metals found the mean amounts of lead was $0.04 \pm 0.016 \mathrm{mg} / \mathrm{kg}(\mathrm{n}=9)$, cadmium 0.0058 $\pm 0.0042 \mathrm{mg} / \mathrm{kg}(\mathrm{n}=9)$, copper $0.126 \pm 0,179 \mathrm{mg} / \mathrm{kg}(\mathrm{n}=$ 8), zinc $2.75 \pm 2.61 \mathrm{mg} / \mathrm{kg}(\mathrm{n}=8)$ and iron was $3.11 \pm 3.27$ $\mathrm{mg} / \mathrm{kg}(\mathrm{n}=8)$. Lilliefors test showed a statistical significance of lead $(p<0.01)$ and cadmium and copper $(p<$ $0.05)$. There was a correlation between the amount of iron and copper $(r=0.97, p=0.030)$ and between the amount of zinc and lead $(r=0.95, p=0.055)$. The results indicate a good quality and health safety of floral honey in accordance with regulations of the Republic of Croatia and European Union.

Keywords: honey, quality, Croatian Army Forces (CAF) 